\title{
THE EVALUATION OF MAPPING AND ITS EFFECTS ON LEARNING IN GEOGRAPHY LESSONS ACCORDING TO SOCIAL STUDIES STUDENTS
}

\author{
Abdullah Balciogullari ${ }^{1}$

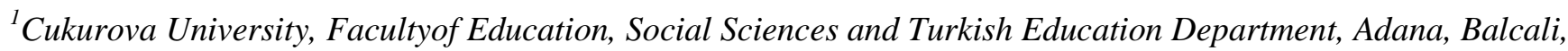 \\ Turkey
}

\begin{abstract}
The aim of social studies course is teach students especially their social and individual roles and responsibilities. It helps students to become productive and effective citizens by developing effective thinking skills. It also teaches students to look at global and social events under the light of information and technology. Geography is one of the leading disciplines in social studies undergraduate programs. In the Department of Social Studies Teaching, there are various geography lessons in undergraduate program as a compulsory course for the first three years. In order to be able to save geography lessons from recollection and to use available information, geographical skills should be applied and activities related to these should be done in the lessons. Practice in geography is more successful than in the theoretical direction. Consequently geography should be taught as a practical course. Geographical skills are very important in teaching geography. Various skills should be given to students in geography teaching. Map studies are the first of geographical skills. Geographical skills include activities related to maps and fieldwork. Within this context the main skills are; plans, maps, globes, atlases, coordinates, use of symbols and direction findings and in instruction of geography using mappings and globes, are necessity. Maps are crucial in geographical skills. Students should learn with a map, instead of learning about the map and learning the map. Maps are symbolic representations that facilitate configurationally understanding of the represented space. Maps enhance our geographic knowledge about the physical and social worlds, promote spatial thinking and spatial skills, facilitate abstract and logical reasoning, and support a wide range of thinking and problem-solving tasks. Once we can see a spatial structure on a map, we can start reasoning spatially by asking "how" and "why" questions. Mapping is traditionally a comprehensive representation scheme that provides the best motivation for systematic data collection, management and mapping. Making, using and reading maps is very important and compulsory and it requires an experience that includes many sub-skills. The use of maps embodies the events and rescues the student from memorization. Moreover the maps are remarkable and it embodies abstract situations by saving time. Even today, is observed that in Turkey still maps, tables and charts reading or interpretation is insufficient. One of the most important reasons for this is not to have enough time in schools to read and interpret maps. This study assesses the potential of this line of research to improve geography education
\end{abstract}

Keywords: social studies, geography, mapping, instruction

\section{INTRODUCTION}

The course of social studies teaches to students especially their social and individual roles and responsibilities. It helps students become effective and productive citizens by developing effective thinking skills. It also teaches students to look at global and social events under the light of information and technology [1]. Constructivist approach has been started in Turkey since 2004. Accordingly, the education system which includes visual elements that students are active has encouraged. Particularly is trying for permanent learning by using material in the teaching of knowledge skills and concepts [2]. Social studies are a very broad field and it is the integrated study of the social sciences and humanities to promote effective citizens. According to the curriculum in Turkey, Social Studies course takes information from anthropology, archaeology, economy, philosophy, sociology, law, citizenship, history and geography and presents this information in a systematic way.
Course of geography is one of the main courses in social studies and significance of geography in the social studies curriculum is indisputable. Especially in the developed countries, geography is a discipline very important. Actually, it will be more accurate to enter the XXIst century with only good geography education.Recently is often discussed on how geography should be taught and it is emphasized that geography should be removed from a course rote learning. In order for geography to become a comprehensible and loved lesson geographical skills must be acquired. In geography lessons activities which related to geographical skills should be done. Today, the reality is that geography is developing as applied science [3]. In addition, the findings of geography are more dominant than theoretical ones [4]. Geography education in schools, are concerned with students this academic knowledge. Geography education, on the other hand, helps students improve their worldviews [5]. 
In geographical skills mapping takes place on the top and using map skills in teaching geography is very important too. Geographical skills are explained by Karabag as follows [6]; "Geographical skills include activities related to maps and fieldwork. The main skills in this context are; plan, map, sphere, atlas, coordinates, use of symbols, direction assignment. Increasingly prevalent and increasing use of computers can also be evaluated in geographical skills (such as CBS)." Various investigations have revealed that lack of geographical and mapping skills [7] and geographic literacy [8] negatively impact on teachers' preferences in teaching geography. Because these tools; essence of geography, basis of the geography and most necessary instructional device [9]. Students should learn with the map instead of learning about the map [10]. Map reading is very important in real life skills. 'Mapping and other graphic activities are included in the basic skills of communication'. These skills are necessary on a daily basis and construct place knowledge [11]. In using geographical skills, exploiting maps and spheres is a necessity [12]. Maps are useful tool to help readers enter perspective and develop a sense of place. When the story reveals a real or imaginary field, it makes a special helper [13]. Students are expected to read and understand maps, as well as plan, map. Both educational and non-educational community the first thing that comes to mind is the geography. Mapping, using and reading maps are very important and necessary and it includes many subskills [14].

Map is a representation, usually on a flat surface, as of the features of an area of the earth or a portion of the heavens, showing them in their respective forms, sizes, and relationships according to some convention of representation. Maps are visual materials created by transferring the information of the place on paper. Maps are not only a teaching tool for topics in social studies, but also a tool that is often used in everyday life [15]. Maps are the most important means of responding to the question of how to navigate from one location to another easily. In addition, with the development of navigation technology, it is used to find directions from maps and to understand our location. Maps are not only a teaching tool for topics in social studies, but also a tool that is often used in everyday life. Maps are the most important means of responding to the question of how to navigate from one place to another easily. We also use navigation to improve navigation and to navigate through maps and to understand our location. Maps make it easy to remember by drawing attention [16] Maps are visual communication tools that summarize information. According to Sahin, maps evoke interest and attention in the students, simplify the content by making it easier to understand, make the teaching vivid and clear and allow practicing on the learning subject [17]. Maps can present information such as roads, public buildings, city settlements, city borders, natural resources, lakes, rivers, coasts, mountains, valleys or arid and wetlands. Maps are important for showing the distribution of the natural environment and their causes and consequences. However, it can be said that there are some hesitations about whether this skill in the program can be used effectively in daily life [18].
In education faculties, geography has an important place in teaching social studies. Undergraduate students are taught various geography lessons as compulsory courses for the first three years. These are General Physical Geography, General Human and Economic Geography, Turkey Physical Geography, Turkey Human and Economic Geography, Country Geography and Political Geography.

\section{METHOD}

In this study was used qualitative research method in order to reveal the views of the students on mapping skills in geography lessons.

\subsection{Working Group}

Map study has been carried out by students Social Studies Education Department who study in two and third years. After the study, a total of 14 students were interviewed that these students were determined randomly. The working group of the study is composed of 14 students who continue to undergraduate program of Social Studies Education at a state university 2016-2017 in the academic years. As it is stated in Table 1, 14 students participated in the study from Social Studies Education Department.

Table -1: Distribution of the students according to their gender

\begin{tabular}{|l|l|l|l|l|}
\hline Gender & \multicolumn{2}{|l|}{ Second Grade } & \multicolumn{2}{l|}{ Third Grade } \\
\hline & f & $\%$ & f & $\%$ \\
\hline Female & 4 & 58 & 3 & 42 \\
\hline Male & 3 & 42 & 4 & 58 \\
\hline Total & 7 & 100 & 7 & 100 \\
\hline
\end{tabular}

According to the purposive sampling, 7 of these students are in the second year $(50 \%)$ and 7 of them are in the third $(50 \%)$ year and $50 \%$ of these students are male, $50 \%$ are females. As it is stated in Table 1, the interview was conducted to 7 female and 7 male students who are randomly selected with the second and third grades of Social Studies Education Department.

\subsection{Data Collection Tool}

Students of Social Studies prepared maps for geography lessons during the fall semester. In order to find out the effect of mapping, attitudes and thoughts of the students about mapping were interviewed at the end of the studies a semi-structured and open-ended interview which consist 6 questions. Students studying in the Department of Social Studies Education prepared maps for geography lessons during the fall semester. In order to find out the effect of mapping, attitudes and thoughts of the students about mapping were interviewed at the end of the studies a semistructured and open-ended interview which consist 6 questions. 


\subsection{Data Collection and Analysis References}

Social studies students prepared maps in courses of Turkey Physical Geography and Turkey Human and Economic Geography in fall semester of 2016-2017 academic years. In order to discharge the work students have prepared three maps -geographical formations, climate and hydrograph- in course of Turkey Physical Geography which is second year course. They have prepared three maps too-settlement, population, agricultural and industrial products- in course of Turkey Human and Economic Geography course which is third year course.

Before the map studies for Social Studies students' preparatory studies were taught for three weeks to transform atlas maps as teaching material. During this preliminary study were given basic information about the map, scale, frame, legend and how they enlargement the small atlases maps $(\mathrm{A} 2$ size $=594 \times 420 \mathrm{~mm})$ by photocopying.

In the study for the course of Turkey Physical Geography, the students have placed symbols on the map; mountains, plains, plateaus, climate data, main rivers and lakes of Turkey. In course of Turkey Human and Economic Geography, they symbolized Turkey's major cities, population distribution and major agricultural and industrial product. Students obtained the current information from the official statistical institution tuik.gov.tr and showed their distribution by forming the production amounts according to the regions.

During this map study was developed an interview form by the researcher. This interview form was presented to four different experts. The questions which accepted by the experts were placed on the form. Consisting of open-ended questions was applied to the participants after the mapping studies. Six open-ended questions were used in this interview form. In the questions, participants were asked to identify the problems they encountered in mapping and to determine impact on their learning. The questions in this interview form are;

What difficulties have you encountered during the mapping? Do you have any difficulties in obtaining data? What kind of difficulties?

What difficulties encountered during placement of information?

How is your feeling about map studies?

Are there any changes in your attitudes before and after the study?

Do you think placement of information on the map was effective on your learning? How?

What is the effect of mapping studies on your daily life?

In this survey were given the answers, opinions and evaluations which given by the participants to the research questions. The results of the practice that obtained from interviews were analyzed with the method of descriptive analysis. Opinions read carefully by the researcher. In this context, related codes (concepts) are taken notes and codes list was created. The code list which obtained was divided into the themes according to the objectives of the researcher and the themes are reported in a certain order. The report includes comments that make it possible to generalizations and meaningful. For the reliability and validity of the work was quoted from the data.

This study was prepared to determine the positive and negative aspects of the effectiveness of mapping, effects on learning within the scope of geography lessons of Social Studies students. In this study; the findings that obtained from the views of the participants were assessed in turn it has been identified the difficulties they encountered during the map preparation, the attitudes towards mapping, the effects on map reading and interpretation, and the effects of mapping on the learning of subjects.

\subsection{The Views of Students about the difficulties of}

\section{Mapping}

As seen on the Table 2, more than half of the social studies student had difficulty in creating maps initially. Students especially stated that they did not know exactly what they were going to do at the beginning of the map preparation and therefore they have difficulty in mapping and later on they did not have any difficulty. According to the interviewed students, the most common difficulties are magnification the map, scale calculation, accessing and placement the data, symbolization, map painting and timeconsuming.

Table -2: The difficulties of mapping

\begin{tabular}{|l|l|l|}
\hline Theme & Frequency & $\%$ \\
\hline skill deficit & 14 & 100 \\
\hline magnification the map & 10 & 71 \\
\hline placement of the map & 8 & 57 \\
\hline scale calculation & 7 & 50 \\
\hline accessing the data & 7 & 50 \\
\hline placement the data & 6 & 43 \\
\hline symbolization & 4 & 29 \\
\hline map painting & 4 & 29 \\
\hline time-consuming & 2 & 14 \\
\hline
\end{tabular}

All of the students stated that they had not encountered the difficulties that they encountered at the beginning of the map preparation. Some of the opinions of students about map studies are as follows:

"I was very tough at the beginning of the map-working; I was afraid enlarge the size of map. But then I saw that it was not hard. One of the points that I was forced on the mapping was to locate the data. In my opinion, it is the most time-consuming to find this data and place them on the map (S9)"

"I have never mapped before I come to university. I had no idea how to draw it. I was very scared when I started this work. I am particularly troubled about how to enlarge the size of the map. But once I did it, I realized that it was not difficult at all (S7)” 
The students who indicated that they did not have difficulty in making the map stated that "they have worked map before." The fact that students have done such a work before has enabled them to develop a positive attitude towards the activity. One of the students who indicated that they were not forced to draw a map is as follows:

"Already I like geography lessons. When I was in high school we have covered a large number of maps. I was thrilled to hear that it was such a work, and I wanted to get involved immediately. Maybe I can call the painting stage is hard (S12)"

\subsection{The Views of Student about Access to Data}

Students were required to reach a variety of data for mapping in both the Turkish Physical Geography and Turkey Human and Economic Geography lesson in Turkey. At this stage, students have used ways of accessing information.

As seen on the Table 3 almost all of the students identified the map study as "the most compeller stage" to reach the information first. However, the fact that nearly half of the learners were expressed this stage as a realized the learning, understand, application, exploration, obtaining new information. A few of the students in the study also articulated the mapping as tedious, boring, time consuming and exhausting expressions. Two of the students said that they had no difficulty in accessing the information and one of them said it was easy.

Table -3: The views of student about access to data

\begin{tabular}{|l|l|l|}
\hline Theme & Frequency & $\%$ \\
\hline the most difficult & 13 & 93 \\
\hline the realization of learning & 7 & 50 \\
\hline understanding & 6 & 43 \\
\hline application & 5 & 36 \\
\hline learning new information & 5 & 36 \\
\hline time-consuming & 3 & 21 \\
\hline exploration & 3 & 21 \\
\hline tire out & 2 & 14 \\
\hline without difficulty & 1 & 7 \\
\hline easy & 1 & 7 \\
\hline
\end{tabular}

Some of the opinions of students about map studies are as follows:

"I can say that we are very difficult to locate the data which we will place on the map first. I think that's the hardest part of working. It takes a lot of time. When I tried to find the data, I actually got a lot of new information that I did not know before. (S1)"

"It was the most difficult part of the research to find the given information. But when researching this data I obtained new information from various sources. But I think this is the longest part of the study. I have browsed most of the time at the internet for about half an hour to find a piece of information and I have studied a lot of resources (S14)"
"I think that's the hardest part of working, but it's too boring for me at the same time. Like bang one's head against a brick wall. I spent a lot of time to find this information. So it was tired (S10)."

\subsection{The Views of Students about Placement the}

\section{Data on the Map}

As it is indicated in Table 4 students views about placement on the map are respectively; the most important stage, instructive, time consuming, decision-making, deciding, difficulty in symbolization, stage of learning, creating of the knowledge, cooperating, using of knowledge, regulation of the information, pessimism and tiredness. Although the three students may think that they cannot finish the work from time to time, but they said that it is a difficult process to complete. Nearly all of the students stated that drawing the data on the map is the most important stage of the study and they saw this stage as the shaping of the map.

As seen on the Table 4, majority of the students said that the longest running phase of the study was drawing data on the map. Seven students stated that they saw this stage as the last stage of the study. The same students also stated that it was so difficult because it was the most important part of the study. Otherwise one of the students stated that it was difficult because he was afraid to make mistakes.

Table -4: The views of student about access to data

\begin{tabular}{|l|l|l|}
\hline Theme & Frequency & $\%$ \\
\hline the most important stage & 15 & 100 \\
\hline instructive & 14 & 100 \\
\hline deciding & 8 & 57 \\
\hline time consuming & 7 & 50 \\
\hline construction of knowledge & 7 & 50 \\
\hline difficulty in symbolization & 5 & 36 \\
\hline cooperating of the & 5 & 36 \\
\hline $\begin{array}{l}\text { regulation } \\
\text { information }\end{array}$ & 4 & 29 \\
\hline pessimism & 3 & 21 \\
\hline tiredness & 2 & 14 \\
\hline difficulty & 2 & 14 \\
\hline
\end{tabular}

Some of the opinions of students about map studies are as follows:

"It was very hard for me to find the information given during the map study. But I think this phase is the most important step in map study. When doing this study, the human brain is forcing the correct drawing of the information. You are looking at a map, an atlas, an internet. With a good or bad grace we concentrated. As such it was also very instructive (S8)"

"I would not have guessed that this work could be so compelling and instructive at the same time. But I was a bit difficult to create legends and symbolization. This stage was the most important part of working after the obtaining information. Because the information is not just placed on 
the map, at the same time learning occurs. So it was a very instructive work (S3)."

"It was a nice study, but I thought I could not finish it in such a time. It took me a long time to complete the work because I did not have enough experience in mapping (S12)."

\subsection{Students Attitudes towards Mapping}

To reveal the attitudes of the working group about the study of the mapping have addressed the question that "How are your feelings and thoughts about forwarding the data to the maps in the geography lessons?" As shown on the Table 5 this question has been reported by the students that map preparation was satisfactory. Besides the positive attitude such as sense of achievement, amusing, achievement, feel comforted pleasurable, taking time, sense of responsibility, tiring, tedious, and reluctance.

Table -5: The attitudes of students towards mapping

\begin{tabular}{|l|l|l|}
\hline Theme & Frequency & $\%$ \\
\hline sense of achievement & 13 & 93 \\
\hline amusing & 11 & 79 \\
\hline feel comforted & 7 & 14 \\
\hline pleasurable & 5 & 36 \\
\hline taking time & 3 & 21 \\
\hline sense of responsibility & 3 & 21 \\
\hline tiring & 2 & 14 \\
\hline tedious & 1 & 7 \\
\hline reluctance & 1 & 7 \\
\hline
\end{tabular}

The majority of the students said that had a negative attitude before the study, but they said that had a positive attitude after the study. Only a small group of them said that they had positive attitudes since the beginning. Otherwise students also reported that they think that mapping was useless, place a burden and bring responsibility.

Some students' views are as follows;

“...Our courses are very busy, I have to admit that I am reluctant to hear this kind of work. But it was a nice work. So I liked it very much. At first I was confused. In fact I have not even mapping in my high school life until these lessons. As the map is shaped, I have enjoyed it (S10)."

"Pleasing side of work was sense of accomplishing a seemingly difficult work. Actually the best part of working was coloring of the map. Because it was aesthetic, as if drawing a picture. I did not have such an activity apart from this course. It was different (S14)."

"I have not been so hand in glove with the map until I do this work. I realized that I was always out of the maps until I did this work. With such a study I felt that I entered into the maps. Before I worked, I thought that mapping would make me very tired. I really liked the work which II put out after the work (S4)".
Ever since I was a child, maps have attracted my interest.. Such a study has contributed a lot to me. I already liked to investigate the map. In my opinion it was very positive (S1)".

Although it was instructive, there is also boring aspects. It takes a lot of time and it was a monotone work. I was tired during placing the data on the map. Especially painting the map was very tiring (S3)".

\subsection{Student Opinions about Effects of Mapping on}

\section{Learning}

In order to expose the effects of map study on the learning of students the question was asked; "Do you think that mapping was effective on your learning in geography course?" As it is seen in Table 6 all of the students who participated in the survey indicated that they thought map study was effective on learning. In this regard, all of the students have used the expression "absolutely instructive". Students have said that this study enhanced their learning, made learning permanent and provided new learning and get skill of using maps and atlas.

Moreover the most frequently mentioned themes are as follows; respectively knowledge creation, application, learning without memorizing, developing a learning strategy, development research skills. One of the students stated that they realized the significance of the map and two of the students indicate that geography could not be learned without maps. The students actually stated that mapping has a positive effect on their learning and despite the difficulty of working the students stated that they had learned the topics after studying.

Table -6: The effects of mapping on learning

\begin{tabular}{|l|l|l|}
\hline Theme & Frequency & $\%$ \\
\hline absolutely instructive & 15 & 100 \\
\hline enhance the learning & 11 & 79 \\
\hline make learning permanent & 9 & 64 \\
\hline skill of using maps and atlas & 6 & 43 \\
\hline knowledge creation & 6 & 43 \\
\hline application & 3 & 21 \\
\hline learning without memorizing & 3 & 21 \\
\hline developing a learning strategy & 2 & 14 \\
\hline development research skills & 1 & 7 \\
\hline $\begin{array}{l}\text { realized the significance of the } \\
\text { map }\end{array}$ & 1 & 7 \\
\hline
\end{tabular}

Some student views are like this;

"Actually, I never thought that map work could be so instructive. There is lots of geographic information in our courses and these are also very important in our daily life. If I had memorized this information, I would soon forget. But the map study provided learning without memorization the information and took part in my memory. I believe that you have increased learning by one hundred percent. I learned so much knowledge with map study (S4)." 
"I already knew in the geography lessons that the maps were very important material in terms of learning and teaching. But after this work I learned how important it is really. I learned very well the data given to us. This work had definitely influenced my learning positively (S7).

"While trying to find the data that was given to us during the application, a lot of new information not found on the list is being learned unwittingly. While trying to find the data given to us during the application at the same time was learned unintentionally a lot of new information that was not listed... I have not been able to study so many atlas and maps before this study. For example after the work, if I hear a place name, I immediately look at the maps. The map has become a habit to me. Because I do not really need to memorize the information (S8)."

\subsection{The Views of Students about the Effects of}

\section{Mapping on Students' Daily Life}

When students are asked about their opinions on the use of the experience acquired in the study of maps, as it is implied in the Table 7, majority of the students stated that the experience they gained with this study, especially geography and history lessons. Otherwise, more than half of the students said that they had their own maps in their minds. The students said that respectively regarding this issue; increasing success, creating map skills, map interpretation skill, self-confidence, having up-to-date information.

Table -7: The effects of mapping on students' daily life

\begin{tabular}{|l|l|l|}
\hline Theme & Frequency & $\%$ \\
\hline Use in lessons & 12 & 86 \\
\hline increasing success & 10 & 71 \\
\hline Create your own map information & 7 & 50 \\
\hline map interpretation skill & 4 & 29 \\
\hline self-confidence & 2 & 14 \\
\hline having up-to-date information & 2 & 14 \\
\hline
\end{tabular}

Some student views are like this;

"With this study I had skills of map reading; I think this is the most important contribution for me. I also understand that it is more enjoyable and instructive to study by looking at the maps, not just in geography lessons, even in history subjects (S3)",

"I always heard such mind maps or location in Lessons. Contribution this study was to create a map in my mind. If I hear any place in Turkey, I know immediately whether it is in the east or west... This gives me happiness and makes me trust myself (S6)".

"I was really bored when I was doing map studies. I struggled to find new solutions such deciding which color to paint the map and symbolization. In a sense, it contributed to the development of imagination. I have to a discipline to finish the work and this was provided by this study (S11)."

\section{CONCLUSION}

This study was conducted in order to determine the opinions of students of Social Studies effect of mapping on their learning and almost all of the students who interviewed stated that a positive effect on learning. An important part of the interviewed students stated that they were not able to map initially, but they did not have difficulty in the progress of the study. In the study the most challenging steps for students were the enlargement of the map, creation of legends, access to information, the placement of information and the painting of the map.

The students used the internet, atlases and maps for obtain the data. The stage of obtain the data is seen as the most challenging and exhausting phase of study however the students stated that new learning was taking place when the data was reached. Nearly half of the students see this stage as the stage in which knowledge is learned.

Students also expressed the difficulty of locating by symbolization the data which they obtained. They also think that this stage is the most challenging stage close to all of the students, but it is also a tutorial.

It is understood that map study is very influential on the learning of the topics. It is seen as difficult and time consuming, but it has a positive attitude because it is a tutorial. Close to all of the students stated that thanks to mapping they learned a lot of knowledge in geography lessons and they have not forgotten that have learned.

\section{REFERENCES}

[1] Gomleksiz, M. N. and Curo, E. (2011). Sosyal bilgiler ogretim programlarinda yer alan degerlere iliskin ogrenci tutumlarinin degerlendirilmesi. Uluslar Arasi Insan Bilimleri Dergisi. 8(1) 95-134.

[2] Ulusoy K. and Gulum K. (2009). Sosyal bilgiler dersinde tarih ve coğrafya konulari işlenirken ogretmenlerin materyal kullanma durumlari, Ahi Evran Universitesi Egitim Fakultesi Dergisi. 10(2), 85-99.

[3] Atalay, I. (1995). Genel Fiziki Cografya. Izmir: Meta Basimevi.

[4] Doganay, H. (1993). Cografyada metodoloji. İstanbul: Milli Eğitim Basimevi.

[5] Hennerdal, P. (2015). Education through Maps: The Challenges of Knowing and Understanding the World (Doctoral dissertation, Department of Human Geography. Stockholm University).

[6] Karabag, S. (2001). Ilkogretim sosyal bilgiler konularinda cografyanın icerigi, ders kitabi inceleme kilavuzu. Ankara: Nobel Yayin Dagitim.

[7] Anderson, K. C., \& Leinhardt, G. (2002). Maps as representations: Expert novice comparison of projection understanding. Cognition and Instruction, 20(3), $283-321$.

[8] Chiodo, J. J. (1993). Mental maps: Preservice teachers' awareness of the world. Journal of Geography. 92(3), 110 - 117. 
[9] Gursoy, C.R. (1961). Kartografya. Ankara: Dil ve Tarih Cografya Fak. Yay.

[10] Tas, H.İ. (2006). Cografya egitiminde gorsellestirmenin onemi: Mekansal algilamaya pedagojik bir bakis. Dogu Cografya Dergisi. 16, 211239.

[11] Spencer, C. and Blades, M. (1993) Children's understanding of places: The world at hand. Geography. 78, 367-73.

[12] Liben, L. S., Myers, L. J., \& Kastens, K. A. (2008). Locating oneself on a map in relation to person qualities and map characteristics. In International Conference on Spatial Cognition (pp. 171-187). Springer, Berlin, Heidelberg.

[13] Gandy, S. K. (2006). Mapping skills and activities with children's literature. Journal of Geography. 105(6), 267-271.

[14] Lloyd, R. (2000). Understanding and learning maps. In Cognitive Mapping Past, Present and Future. New York: Routledge.

[15] Akalin, S. H. et al. (2011). Turkce sozluk. Ankara: Turk Dil Kurumu

[16] Duman, H. (2011). Sosyal bilgiler egitiminde harita kullanimi ve harita kullanimi konusunda ogretmen goruşleri. Unpublished Master Thesis. Uludag Universitesi, Bursa.

[17] Sahin, B. (2012). Cografya ogretmenlerinin tematik haritalara yonelik goruşleri. Unpublished Master Thesis, Egitim Bilimleri Enstitusu, Gazi Universitesi. Ankara.

[18] Koc, H. (2008). Cografya ogretim programindaki kazanimlarin ogrencilerin harita beceri duzeyleri uzerine etkisi. Unpublished unpublished doctoral dissertations. Gazi Universitesi. Ankara.

\section{BIOGRAPHY}

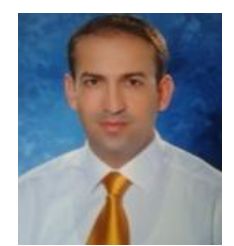

Abdullah BALCIOGULLARI was born in Hatay- TURKEY in 1973. He got his bachelor degree in Geography Department at Ankara University in 1998 in Ankara / Turkey and he wanted to study on instruction of geography he has gat master degree in Curriculum and Instruction Department at Cukurova University in 2004 in Adana / Turkey. He has got doctoral degree in the same department of same university in 2011. He concentrates his studies on historical geography. At the moment he has been working as an assistant professor at Çukurova University, Social Studies Education Department in Adana / Turkey. Currently he is working on geography instruction. 